NGTT Deel 54, Nommers 3 \& 4, September en Desember 2013

Botha, Johan ${ }^{1}$

Stellenbosch University

\title{
Diversity in unity - Voices from the past, the focus on Belhar and the on-going quest for unity
}

\begin{abstract}
"When the reconciliation in Christ becomes visible it will be a sermon that echoes around the world"
\end{abstract}

P. F. Theron (Die Kerkbode, 23 June 1982)

\begin{abstract}
This contribution focuses on the on-going ecclesiological quest by the Dutch Reformed Church (DRC) family to become a visible, living and practicing diversity in unity. It highlights remarkably clear and foundational theological contributions with regard to this matter, by trustworthy voices from inside (e.g. individuals like Botha, Durand, Jonker as well as by several church meetings and synods) and outside (e.g. theologians like J Calvin and K Barth) the DRC Family, in opposition to wrong ecclesiological convictions and practice. In relation to this the core focus of the Confession of Belhar on the church as visible and as diversity in unity, is emphasised as foundational to the character of the church of Christ. Guiding perspectives on this fundamental truth are also drawn from important contributions by Dirkie Smit, in particular from his thoughts on the ecclesiology in the Confession of Belhar.
\end{abstract}

\section{THEOLOGICAL VOICES PRECEDING BELHAR}

Over the past fifty years, the quest for the one visible church of Christ received continuous attention within the Dutch Reformed Church (DRC) family ${ }^{2}$ in South Africa. At times this quest dominated church debates and practices. In the midst of serious discord, trustworthy voices kept calling the church back to its roots and its foundation in Jesus Christ.

Dirkie Smit's contributions gave and continue to give credible guidance in the international discourse on (for example 2008a and b; 2010a) and the practice of church unity within the DRC family in particular (for example 1992; 2010b). He was intimately involved in the birth of the Belhar Confession in 1982. This confession's vivid and self-evident focus on lived church unity

1 Johan Botha is Director of the United Commission for Witness of the DRC family in the Cape (DRC Western Cape, RCA and URCSA Cape). He also is Scribe of URCSA Cape Synod and research associate in the Faculty of Theology, Stellenbosch University. All translations of Afrikaans texts in this essay are the author's own.

2 The four racially/culturally separated DRC denominations/Churches in South Africa in 1960 were the Dutch Reformed Church (DRC- - for whites); Dutch Reformed Mission Church (DRMC - for coloureds); Dutch Reformed Church in Africa (DRCA - for blacks) and the Reformed Church in Africa for Indians). 
NGTT: Oopbron - http://ngtt.journals.ac.za

continues to challenge the fragmented DRC family in South Africa and the church worldwide. ${ }^{3}$

What follows broadly reminds of the nature of the theological discourse that preceded the birth and informs the focus of Belhar, and that this focus should be maintained today.

Discerning contributions before Belhar's adoption in 19864 came from individual voices, ${ }^{4}$ church conferences, associations $s^{5}$ and synods ${ }^{6}$ These called attention to the theological truth that the church as the body of Jesus Christ is fundamentally to be understood as diversity in unity, ${ }^{7}$ comprising of people who naturally have obvious differences, represent diverse cultures, may not prefer each other's company, yet form the one visible, reconciled body (Eph. 2) that confesses and lives the truth that "Christ is all, and in all" (Col. 3:10-11) and that He reigns over this church and over all else (Eph. 1:20-23).

In the early 1960s, three respected voices from different contexts, David Botha, Jaap Durand and Willie Jonker, ${ }^{8}$ emphasised this truth and its implications for the DRC family's ecclesiology

3 Belhar was formally adopted by the Protestant Church of Belgium in 2001 and the Reformed Church of America in 2010. Its is currently under consideration for adoption in 2012 by the Christian Reformed Church of North America and the Presbyterian Church of the USA.

4 Some public voices in the quest for visible church unity in South Africa before Belhar's formal adoption in 1986, besides those mentioned in this article, included Beyers Naudé, Nico Smith, Ben Marais, John de Gruchy, Johan Heyns, Allan Boesak, Bernard Lategan, Adrio König, Bernard Combrinck, Douglas Bax, Willem Nicol, Willem Vorster, G. J. Swart, O’Brien Geldenhuys, Klippies Kritzinger, Willem Saayman, Ettiene de Villiers, Johann Kinghorn, Richard Stevens, A. B. du Toit, Lex van Wyk, Hannes Adonis, Piet Meiring, Lukas Mabusela, Henri Lederle, Chris Loff, Phil Robinson, Daan Cloete, Chris Botha, Jan Mettler, J. W. Hofmeyr, Andrew Esterhuizen, Nico Botha, Gerrie Lubbe and the 123 signatories to The Open Letter of June 1982.

5 For example, the strong plea for visible church unity at the 1979 ecumenical South African Christian Leadership Assembly (SACLA) meeting in Pretoria; the 1981 ABRECSA (Alliance of Black Reformed Christians in Southern Africa) Charter (De Gruchy, 1983); the DRC family workshop on What is Mission? in Bellville during April 1986 (cf. Robinson and Botha, 1986).

6 For example, the serious theological reflections and decisions on visible church unity at the 1975 General Synod of the DRCA, the DRMC synods of 1978 and 1982, the 1983 DRC Western Cape Synod.

7 The enlightening publication in the 1950s by W. A. Visser 't Hooft, then General Secretary of WCC, Tot Eenheid Geroepen (Called to Unity) stressed that unity in Christ calls for its visible expression in common faith, sharing in the sacraments, common ministry and life in community in every place where the church is planted. It does not call for uniformity since the New Testament church was characterised by an almost bewildering diversity of ministries and they rejoiced in the variety of spiritual gifts (1958:109110). The WCC Assembly of 1961 stated that "the unity which God promises and to which He calls his church is a unity of Christians 'made visible as all in each place who are baptised into Jesus Christ ... are brought by the Holy Spirit into one fully committed fellowship, holding the one apostolic faith, preaching the one Gospel, breaking the one bread"' (Braaten 2003:11).

8 D. P. Botha's book, which reflected on the position and development of the members of the DRMC in particular and so called coloured people in general, was published in 1960 . He was pastor in four DRMC congregations (19481980), the actuarius (19621974) and moderator (19741982) of the DRMC, and editor of Die Ligdraer (the official mouth piece of the DRMC) (19791990). Jaap Durand's doctoral dissertation was published in 1961. Durand was pastor in two Xhosaspeaking congregations of the DRCA, was appointed Professor of Systematic Theology at the University of the Western Cape in 1973 and its Vice Chancellor from 1981 to 1994. Willie Jonker's Mission Regulations of the DRC of Transvaal was published in June 1962. He was pastor in two DRC congregations, actuarius of the DRC Northern Transvaal (19611963), and Professor of Systematic Theology at Stellenbosch University from 1971 until 1992. Dirkie Smit interacted closely with all three: Botha tutored him in the practice of congregational ministry in the Bellville DRMC (1975); Smit was an undergraduate and doctoral student of Jonker's 
NGTT Deel 54, Nommers 3 \& 4, September en Desember 2013

and missiology. Their perspectives fundamentally challenged the official position of the Dutch Reformed Church (DRC), ${ }^{9}$ as well as apartheid ideology and practice. This stirred intense debate, caused uneasiness, conversion for some and essentially contributed to the birth of Belhar.

In 1960, David Botha ${ }^{10}$ pleaded on sociological and theological grounds that the white and so called coloured sections of society should be regarded as one people. Botha's view as pastor and church leader on the nature and visible embodiment of the church is particularly relevant. His theological reflections, experiences in congregations and perspective on the relationship between white and coloured people in broader society, led him to oppose the reigning theological convictions and motivation for separation within church and society. He called for one synodic structure in the DRC family and for open membership across the colour line where people resided and worked within the same geographical context. He also argued strongly against colour prejudice amongst white people, resisted the push for physical separation in favour of contact amongst the different groups and races in the church and in society, proposed a new demarcation of presbyteries and regional synods where colour prejudice would no longer prevail and strongly rejected what he called "foolish, blind, irrational class prejudice within the church" (1960:152-157).

(19731979); and he became Durand's colleague at UWC (19812000) and co-authored the Belhar Confession with Durand, Gustav Bam, Izak Mentor and Allan Boesak (1982).

9 See, for example, the report of the ad hoc committee for race relations, appointed by the former Federal Council of white Dutch Reformed Churches in SA: The DR Churches in SA and the Problem of Race Relations (1956). The report describes the belief of the DRC at the time that unity "is to be found in the very nature of the Church of Christ." However, the report also states that "[i]t is not found in the institutionalised or organised Church, which appears in numerous different and often conflicting forms" (7). In its "Doctrinal Approach" the report states that "because of the depraved and finite nature of people, the ecclesia of the New Testament is still imperfectly manifested, realised on earth." The context (for example, racial contrasts and tensions in South Africa) clearly overrides sound theological principles on unity. The synods could, therefore, declare: "In its essence the Church is the one mystical body of Christ before God in its spiritual reality this unity must be stressed as strongly as possible the unity of the Church remains the Christian ideal. Further (paragraph 3): "This, however, does not mean that the one true Church cannot be embodied in separate independent Churches, which in truth confess the Christ of Holy Scripture as their Lord and Saviour (paragraph 5)." Finally, they stated that "the founding and development of independent indigenous churches for the purpose of evangelizing the non-white races of South Africa, was both necessary and in accordance with our understanding of the nature of the Church of the Lord Jesus on earth" (paragraph 7). In the "Declaration of Principles" (paragraph 4) the report used Genesis 11:69 and Acts 17:26 as reference to God's graciousness by which greater diversity was decreed "to restrict the expansion of mankind in its apostasy and insubordination to Him" and "to check the effect of sin" in this way. Paragraph 7 then claimed that "[t]he natural diversity and the different spheres of influence and relationships of authority which God has ordained, are in no way broken down by this unity in Christ, but rather restored and sanctified."See also publications by J. D. Vorster, F. J. M. Potgieter and others during the 1970s. In the 1978 publication on Pluriformity and Unity, Vorster wrote: "Nowhere in Scripture is the visible revelation of the unity stated as characteristic of the essence of the Church. It belongs to the wellbeing and not to the being of the Church" (Vorster 1978:78). Later he concurs with T. N. Hanekom, onetime Professor of Church History and Church Law at Stellenbosch: "Let every Church keep its own form, government and authority." Vorster concluded that church pluriformity is acceptable according to Reformed polity and practice, and correct in principle where one finds great ethnic differences $(1978: 85,86)$. The story of the growing opposition to these theological convictions and practices that resulted in the state of confession and the birth of Belhar (1982) is told in Botha and Naudé, 2010.

10 This was also the year of the Sharpville killings, Langa unrest and Cottesloe Church Consultation 
NGTT: Oopbron - http://ngtt.journals.ac.za

With regard to the need for adjustment on the terrain of the church Botha argued

that "the complete absence of ethnological and cultural distinctiveness of the "Coloureds" made the apartheid formula and even the Tambaram formula for indigenous churches, in distinction of white churches, never applicable to them."

In conclusion, Botha stated that "[a]ll reasons advanced for separation can be unmasked as rationalization. This kind of prejudice is sinful and the church itself will be guilty of sin if it does not combat it with all its power"(1960:157).

Jaap Durand also challenged the reigning theological convictions of the time. In 1961, in his doctoral dissertation he claimed that "kerugmatik exigencies" (prerequisites) necessitated an indigenous development of the church in the mission field - not only for the internal life of the church, but also for its concomitant missionary witness. However, Durand insisted, such an indigenous development, taking the particular mission context and distinct needs into account, should never lead to a breach of the church's visible unity. The call is for one denomination within which there is room for diversity (Durand 1961:260). In his dissertation and articles he wrote on the ecumenical church (cf. Van Wijk 1964 Durand theologically emphasized the focus of the Reformed fathers (Calvin in particular, as well as Articles 27 to 29 of the Belgic Confession) on the unity of the church as anchored in Christ himself, and which does not exist in the visible church alone but has a clear bearing on the "visible church so that each one of us is united in brotherly unanimity, united [saamverbind] together with all the children of God." Because the catholicity and unity of the church is a given in Christ, Durand claimed, we should strive and wrestle to make it visible (in Van Wijk 1964:34-39). Durand stated that wherever the church may be, there the biblical demand for the unity of the church simultaneously applies. The disunity of the church undermines its defense against the diversity of powers that it faces (Van Wijk 1964:83-84).

In 1961, Willie Jonker heralded that a people (volk) should not structure the church. ${ }^{12}$ He thus opposed the regulation (Article 3) of the Transvaal DRC according to which only white people were allowed to be members of the DRC and, as actuaries, Jonker omitted it from the synod's church orderly regulations (1998:53,54).

Jonker also identified clear discriminatory tendencies in the synod's regulations on mission. His consequent 1962 publication in this regard pleaded on theological grounds for visible church unity. Jonker stressed that we may never become complacent about the existing disunity of the church, let alone defend disunity or encourage the church to abandon its pursuit of visible unity of the body of Christ.

According to Jonker, the New Testament knows only one church. When the plural form for church is used, it indicates the various local congregations in which the one church of Christ is revealed. Although each congregation locally constitutes the church in its totality, these congregations are not separate from each other but are in the closest possible association.

11 In the preface to the book, leading Afrikaans author N. P. van Wyk Louw declared: "the brown people are our people and they belong with us" (1960:v). Botha and Louw's perspectives received widespread support in society but also solicited strong opposition in political circles. According to the publisher, reaction came from incumbent Prime Minister Hendrik Verwoerd himself who, in opposition to Botha and Louw's perspectives, promised not to deviate from the apartheid path (Rousseau 1993:14).

12 Jonker later explicitly declared that his own ecclesiology in the 195060s could not be aligned with apartheid (1998:43). 
NGTT Deel 54, Nommers 3 \& 4, September en Desember 2013

The essential unity that the one, catholic, Christian church already possesses in Christ should be revealed in a relationship encompassing churches in all locations and countries (1962:25).

"The manifestation of the multitude of churches that stand over and against each other is a sinful dissension [sondige verskeurdheid]", Jonker stated (1962:28). He continued his plea that

"[w]e may not rest, before the different churches of whom we cannot say that they represent the false church, also visibly show their unity. All that is still church should, in obedience to the Word of God, be united. This will not be happening spontaneously. We should wrestle to come to agreement with each other in the light of the Word. But this alone will be true ecumenicity that the question of truth will be put in all seriousness and that the unity of the whole body of Christ will be earnestly sought. Only in doing so can a responsible and common witness be rendered in response to the false church, in whichever shape it may reveal itself (Article 29, Belgic Confession)" (1962:28).

Jonker claimed that "there should only be one church of Jesus Christ in the world." National borders, nation (volk), language and cultural differences should not divide the church of Jesus Christ (1962:29).

Jonker also emphasised the necessity for indigenisation in order to penetrate all the layers of peoples' and societies' thinking and practices. But he was also clear about what that could not mean: "After all had been said, we must however maintain that it should not mean that a separate church should come into being for each people [volk]." Jonker was clear that "the diversity of nations must be revealed within the one communion [verband] of the church of Christ on earth" (1962:30-31).

"This other thing also is to be ranked among the chief evils of our time, viz., that the churches are so divided, that human fellowship is scarcely now in repute amongst us, far less that Christian intercourse which all make a profession of, but few sincerely practice Thus is it that the members of the body lie bleeding. So much does this concern me, that, if I could be of any service, I would not grudge to even cross ten seas, if need be on account of it (in Vischer 2000:29)."13

13 Voices from 1981 and 1982 (the year of the birth of Belhar) indicated the same, for example: The ABRECSA Charter (1981) stated: "The unity of the Church must visibly be manifest in the one people of God. The indivisibility of the body of Christ demands that the barriers of race, culture, ethnicity, language and sex be transcended" (in De Gruchy 1983:161, point 1.1.e); the doctoral dissertation of Hannes Adonis, pastor in the DRMC on the Cape Flats (later Professor of Church History and Church Law at UWC and Stellenbosch), analysed the DRC's mission policy of 1933 and emphasised the incorrect use of diversity as a principle to structure community in church and society (Adonis 1982:200ff.). With his paper of April 1986 (1986:163-165), Adonis assisted colleagues to grasp the unfortunate consequences of this policy and to eventually confess the DRC family's guilt with regard to the disunity of the church (cf. Robinson and Botha 1986:62-86). In his article on the context of the so called Open Letter (Bosch, König and Nicol 1982:33-52), David Bosch stated that the quest for visible unity has to do with mission. If the carriers of the gospel are untrustworthy, then the gospel they preach becomes suspect. However, if their daily conduct radiates love, forgiveness and reconciliation, the world outside the church is drawn to Christ by the magnetism of their witness (1982:52). Bosch concluded with what Flip Theron (later Professor of Systematic Theology at Stellenbosch University) wrote in Die Kerkbode (the official mouthpiece of the DRC) of 23 June 1982: "When the reconciliation in Christ becomes visible among us, it will be a sermon that echoes around the world." 
NGTT: Oopbron - http://ngtt.journals.ac.za

Calvin's passionate and consistent commitment to the unity of the body of Christ was lived out within the reality of an already fragmented church. In the midst of division, he acknowledged the one Lord of the one Church, stressing repeatedly that Christ's body is one, that there is no justification for a divided church, and that schisms within churches are a scandal (WARC, 2007).

Calvin's willingness to mediate controversial matters such as the Lord's Supper, and his tireless efforts to build bridges at every level of church life, still stand as a contemporary challenge to this day for churches to understand the causes of continuing separation and, in accordance with Scripture, to strive towards visible unity by engaging in concrete ecumenical efforts, all for the sake of the gospel's credibility in the world, and the fidelity of the church's life and mission (WARC, 2007). ${ }^{14}$

Karl Barth reiterates Calvin's perspectives, gives guidance regarding the nature of the unity of the church, and stresses that its disunity ought to be rejected (1974, CD 4/1:675-677 On the Being of the Community). For Barth many churches imply many Lords, many Spirits, many Gods. He claims:
"There is no question about it: to the degree that Christendom exists in Churches which are really different and opposed to each other, to the degree she is denying in practice what she acknowledges in theory, the unity and uniqueness of God, Jesus Christ, the Holy Ghost ... [Therefore] whatever good reasons there may be for the beginning of such schisms, whatever serious obstacles there may be to ending them, whatever interpretations and extenuations may be made of them, nothing alters the fact that every schism is as such a dark riddle, a scandal."

In Barth's opinion the whole of Christendom ought at least be one in this: that wecan think of it only as a constant subject of repentance, and not on any of our parts a repentance to be expected from others, but one in which we are willing to meet others, cost what it may.
"Anyone who is prepared to come to terms with schism in the Church, being at ease with it, tranquil about it, may be a good loyal believer in some sense that belongs to his [sic] particular denomination - a good Roman or Calvinist or Orthodox or Baptist - but he must not think that he can possibly be a good Christian. He has not honestly and seriously believed and known and confessed the una ecclesia [one church]. For the una ecclesia cannot exist if there is a second or third side by side or opposed to it. It cannot exist in opposition to another church. It cannot be one among many."

Barth stresses that the New Testament knows nothing of the plurality we know of in the church today. In view of the being of the community as the body of Christ it is - ontologically - quite impossible, he argues; it is possible only as sin is possible. Thus Barth is clear that we should not deduce this plurality of churches,
"as if though the contradictions are necessities from the una ecclesia, as though this Church had to be divided into the churches of the East and the West, the Church of the West into Romanist and the Evangelical, the Evangelical Church into the Lutheran and Reformed and Anglican, as though there was no trouble, no disorder ..."15

\footnotetext{
14 Cf. also the WARC 2000 publication by Vischer, Pia Conspiratio, Calvin's Legacy and the Divisions of the Reformed Churches Today.

$15 \mathrm{Cf}$. CD 4/1, "upbuilding of the community", perspective on the confession: credo unam ecclesiam in the
} 
NGTT Deel 54, Nommers $3 \& 4$, September en Desember 2013

\section{BELHAR'S FOCUS ON DISUNITY IN UNITY}

Despite the authoritative theological voices in South Africa to the contrary, the lack of visible unity was evident at the beginning of the 1980s. Within the established separate Dutch Reformed Churches, denominational branches for different races and cultures were firmly believed to be theologically sound doctrine and church practice. ${ }^{16}$

The prophetic calls for ecclesiological conversion were not heeded. Nor were the passionate pleas for visible church unity by the national synods of the DRCA (1975) and the DRMC (1978) attended to by the DRC. ${ }^{17} \mathrm{~A}$ growing disunity and estrangement amongst the DRC family of churches and its members in South Africa was the unfortunate result.

In South African society between the late 1970s and early 1990s, the political polarisation between race groups became unmanageable. Peace and calm disappeared, communities organised protest actions and the government effectively lost control. On the borders the South African Defence Force was waging war and domestically a low level civil war developed.

With the DRC family caught up in these worsening conditions and while the church was struggling to find fundamental, biblical guidance to address the reigning false doctrine on unity, the Belhar Confession was born. The DRMC General Synod of October 1982 basically confessed that the church ${ }^{18}$ could no longer contradict the gospel with its order, its life and its witness (Smit, 2010b).

Belhar is a remarkable ecclesiological confession (Botha and Naudé 2010:176), at heart it is a confession about the unity of the church (Smit 2010a, par. 6). In 1982, the DRMC was convinced that on the issue of unity no differences of opinion should exist because the heart of the gospel clearly teaches such unity. The opposite - disunity between fellow believers - was rejected as an error, "a false doctrine, which misleads many, without them realizing it" (Smit 2010b).

Belhar confesses three things about unity? ${ }^{19}$ First, that the church is already one, called from the entire human family into unity, as a gift, within the powerful bond of the Holy Spirit; one with our brothers and sisters, irrespective of who or where they are. We cannot choose or refuse our brothers and sisters, we receive them. We are invisibly and spiritually one; only one church, one body of Christ, one people of God, one "building of the Spirit". We believe and confess this gift of unity, the reality of this unity, this bond of the Spirit.

Second, this spiritual unity must be visibly lived and practised. The reconciliation in Christ must be recognisable in the church - man and woman, slave and free no longer count. The unity is a gift but also a calling (an obligation) and must be pursued, sought, and must constantly be built up. Christ binds us together as a visible community of faith. Reconciled with God and with one another, we are given the opportunity to mutually serve and enrich one another

face of scandal of disunity.

16 Cf. J. D. Vorster 1978. Contributors to the latter work were F. J. Botha, F. J. M. Potgieter, E.P.J.

Kleynhans, C. I. van Heerden, D. S. Snyman, J. H. Roos, A. P. Treurnicht and S. J. Eloff.

17 The DRC rather continued its theology of separation in its policy document of 1974, Ras, Volk en

Nasie. Volkereverhoudinge in die Lig van die Skrif (Race, People and Nation. Race Relations in Light of

Scripture).

18 Belhar's birth and its context are recorded in Botha and Naudé 2010:37-72.

19 Smit summarised the confession's focus on unity in three points at the URCSA Cape Synod on 27

September 2010 (Smit 2010b). f also Botha and Naudé 2010:61-63. 
NGTT: Oopbron - http://ngtt.journals.ac.za

with our variety of gifts, opportunities, backgrounds, convictions, languages and cultures. This was not, of course, a novel idea. The Heidelberg Catechism underlines this unity of the faithful and teaches - in Q. and A. 54 and 55 - that we are called to use our gifts for the wellbeing and benefit of one another.

Everything that threatens this living unity must be resisted and has no place in the church. All division, enmity and hate amongst people and groups are sins and, therefore, already conquered in Christ. The unity must become visible so that the world may believe, that is the simple point, so that the world may see that the unity in the church transcends all personal, natural and cultural differences and divisions, so that the world may believe in the gospel of the love of God (Jn. 17:20-23).

Third, regarding the way unity should become visible: What does visible unity look like? What are we striving for? What do we long for and work for? What do we pray for and what do we dream of? Belhar responds to this question with a threefold confession. The visible unity a) includes, not excludes, a rich and wondrous variety and diversity, b) can take form only in freedom and not under constraint and pressure, coercion and force, c) is diversity and freedom "within the one visible people of God" - this is what we confess, pray and work for.

Belhar rejects any teaching that uses diversity or sinful division among people in a manner that hinders or disrupts visible and effective church unity. The view should be condemned that believers may share the same confession while being organised in different ways in different churches because of the existence of diversity and the absence of reconciliation. Finally, Belhar rejects any teaching that refuses to declare it sinful not to pursue the visible unity of the church as a precious gift.

\section{THE QUEST CONTINUES}

Smit stated before the URCSA Cape Synod in 2010 that "[p]recisely this visible unity was at stake then [in 1982 and before - JGB], as it still is today". He emphasised that

"[m]any confess the invisible and spiritual unity but deny that it needs to become visible, living and practical. We deny it with our words, with our actions, with our omissions. We confess with the tongue, but do we truly oppose everything that threatens the visible unity?"

This, Smit maintained, is "the challenging question everywhere in the worldwide church today" (Smit 2010b).

It is true that some strategic, hope giving interactions and structural unification took place in and around the DRC family with regard to the practice of visible diversity in unity. Since 1982 Belhar became a yardstick in the structural church reunification process between the members of the DRC family. Occasionally hope giving decisions were taken by some DRC synods with regard to church unity. ${ }^{20}$

20 One example is the following decision taken by the DRC Western/Southern Cape Synod in 1987 (Acts 161: point 2): "Synod is in favour of one church relation (denomination) for the DR Church family. One church relation is formed when separate congregations with the same confession and church polity are grouped together in broader church gatherings to give effect to essential church unity. Such a church relation may be structured in various ways" [my translation - JGB]. Since this decision was taken, several DRC General Synods (between 1990 and 2007) resolved to pursue visible church unity with sister 
NGTT Deel 54, Nommers $3 \& 4$, September en Desember 2013

Laudable and credible (yet partial) unification did occur: in the 1994 reunification of the DRMC and DRCA to form the Uniting Reformed Church in Southern Africa in the light of Belhar's call for diversity in unity; in the establishment of the United Synodic Commission for Witness (CFW) of the DRC family in the Cape region in 1991; in the joint congregational ministries of the DRC family in the Western Cape from 2002 to 2010; in the unification of the diaconal/ service ministries of the DRC family in the Cape region since 2006; in the national United Ministry for Service and Witness (UMSW) of the DRC family of churches in the RSA and Namibia through a process that started in the 1990s and that was concluded in 2008; in the establishing of the united presbyteries of Wesland, Stellenbosch and Caledon Presbyteries; in the joint efforts regarding theological training at Stellenbosch, Pretoria and Bloemfontein; in joint projects in which members of the DRC family combine their efforts annually to develop tools for use in congregations, for example, the Lectionary for preaching, liturgical guidance, Bible study and group interaction, as well as guidelines for the Week of Prayer and Pentecost (Botha and Naudé 2010:73-93; 156-164).

However, the separate churches within the DRC family in South Africa have still not been fully united into the one, visible church of Jesus Christ for which he prayed and gave his life, which the gospel proclaims and Belhar confesses. The quest continues for the credible, visible unity to which we are called in Scripture, which is more than agreeing and declaring together that we are one, which also includes a process of open worship, of life together, of the healing of memories, of continuous praying for this unity, of journeying together, of together seeking compassionate justice ${ }^{21}$

\section{BIBLIOGRAPHY}

ABRECSA (1981). 1983. Charter. In De Gruchy, J. and VillaVicencio, C., Apartheid is a Heresy. Cape Town: David Phillip.

Adonis, J. C. 1982. Die Afgebreekte Skeidsmuur Weer Opgebou. (The Demolished Wall of Separation Rebuilt.) Amsterdam: Rodopi.

Barth, K. 1974. Church Dogmatics 4/1 - The Doctrine of Reconciliation. Edinburgh: T\&T Clark. Braaten, C. E. and Jenson R. W. (eds.). 2003. In one Body - Through the Cross. The Princeton Proposal for Christian Unity. Grand Rapids, MI: Eerdmans.

Bosch, D. J., König A. and Nicol W. D. 1982. Perspektief op die Ope Brief. (Perspective on the Open Letter.) Cape Town: Human \& Rousseau.

Botha, D. P. 1960. Die Opkoms van Ons Derde Stand. (The Rise of Our Third Estate.) Cape Town: Human and Rousseau.

Botha, J. G. 1992. Kerkeenheid en die Getuienistaak van die Kerk. (Church Unity and the Witness of the Church.) Apologia, Nov. 1992, 7(1\&2), 26-42.

Botha, J. G. 1992. Mission in Unity? A Challenge to Faith and Mission of the South African Council of Churches. SACC Publication. Johannesburg: SACC.

Botha, J. G. 2007a. Mekaar se Broers en Susters, Omdat Jesus Dit Wil! 'n Perspektief op die Storie van die Verenigende Gereformeerde Kerk in SuiderAfrika (VGKSA) vanaf 1994 tot 2006. (One Another's Brothers and Sisters, Because Jesus Wills It! A Perspective

on the Story of the URCSA from 1994 to 2006.) In Nel, R. and Du Toit, H. (eds.), Ons Pelgrimstog na Eenheid. (Our Pilgrimage to Unity.) Pretoria: University of Pretoria Press, Dept. Church History.

Botha, J. G. 2007b. "We Owe the World Good Theology" - On Reformed Faith and Public Theology. In honour of D. J. Smit. NGTT 48(1\&2), March \& June 2007, 333-344.

Botha, J. and Naudé P. 2010. Goeie Nuus om te bely. Die Belydenis van Belhar en die pad van aanvaarding.

churches in the RCA and Namibia (cf. Botha and Naudé 2010: chapters 5, 7 and 8).

21 Cf. the probing papers by Scherle (2010) on "how unity is deepened" and Smit (2010a) in response to the question on "the kind of unity we want (need) and should pursue today. 
NGTT: Oopbron - http://ngtt.journals.ac.za

Wellington: Bible Media. (English edition published as Good News to Confess. The Belhar Confession and the Road of Acceptance. Wellington: Bible Media, 2011.)

De Gruchy, J. and VillaVicencio C. 1983. Apartheid is a Heresy. Cape Town: David Phillip. Durand J. J. F. 1961. Una Sancta Catholica in Sendingperspektief. (Una Sanct Catholica in Missionary Perspective.) Amsterdam: Ten Have N.V.

Durand, J. J. F. 1964. Ware Ekumenisiteit - Die Gereformeerde Vaders. (True Ecumenicity - The Reformed Fathers.) In Van Wijk, A. J. (ed.), Die Ekumene. (The Ecumenical Church.) Stellenbosch: Kosmo.

Durand, J. J. F. 1984. 'n Belydenis - Was Dit Werklik Nodig? (A Confesion - Was It Really Necessary?) In G.

D. Cloete en D. J. Smit, 'n Oomblik van Waarheid. (A Moment of Truth.) Cape Town: Tafelberg.

Geldenhuys F. E. O'B. 1982. In die Stroomversnellings. (In the Rapids.) Cape Town: DRC. Information Bureau of DRC (Tvl. and Natal). 1960. Statement on Race Relations. Johannesburg: DRC.

Jonker, W. D. 1962. Die Sendingbepalinge van die Ned. Gereformeerde Kerk van Transvaal (The Mission Regulations of the DRC of Transvaal.) In the Series Kerk en Wêreld. (Church and World.) Theological Studies on the Mission of the Church in the world. No 4. Pretoria: Ned. Geref. Boekhandel.

Jonker, W. D. 1965. Aandag vir die Kerk (Attention for the Church). No 1 in the series: Die Stryd om die Kerk. (The Struggle for the Church.) Potchefstroom: Potchefstroom Herald.

Jonker, W. D. 1998. Selfs die Kerk kan Verander. (Even the Church can Change.) Cape Town: Tafelberg. Lückhoff, A. H. 1978. Cottesloe. Cape Town: Tafelberg.

Meiring, P. and Lederle, H. I. 1979. Die Eenheid van die Kerk. (The Unity of the Church.) Cape Town: Tafelberg.

Nel, R. and Du Toit, H. (eds). 2007. Ons Pelgrimstog na Eenheid. (Our Pilgrimage to Unity.) Pretoria: Univ. of Pretoria, Dept. Church History.

Potgieter, F. J. M. 1977. Gesamentlike Aanbidding. (Joint Worship.) Pamphlet. Cape Town: NG Kerk.

Potgieter, F. J. M. 1977. 'n Oorkoepelende Sinode? (An Overarching Synod?) Pamphlet. Cape Town: NG Kerk.

Potgieter, F. J. M. 1978. Eenheid en Veelvormigheid Prinsipieel Verantwoord. (Unity and Pluriformity Principally Justified.) In Vorster, J. D. (ed.), Veelvormigheid en Eenheid. Cape Town: NG Kerk. Robinson, P. and Botha, J. (eds.). 1986: Wat is Sending? (What is Mission?) Malmesbury: Swartland Drukpers.

Rousseau, L. 1993. ' $n$ Toevlug in die Weste. (A Haven in the West.) Cape Town: Rubicon. Scherle, P. 2010. Wie Einheit vertieft wird - der KirchengemeinschaftsProzess der GEKE aus kirchentheoretischer Sicht. (How Unity is Deepened - the process of Church Fellowship of the CEPE, from a churchtheoretical perspective.) Paper delivered at Consultation of the CPCE and the Ev. Church in Hessen Nassau on "The Community of Protestant Churches in Europe as a fellowship of Churches". 1519 September 2010. Online at http://www.zentrumoekumeneekhn.de/fileadmin/content/Materialien/ Dokumentationen/ GEKE_Dokumentationen.pdf. [2010 March, 30].

Smit, D. J. 1989. “... Om Saam met die Heiliges Christus te Ken." Persoonlike Indrukke van 'n Ekumeniese Waarheidsoeke. ("To Know Christ with All the Saints." Personal Impressions of an Ecumenical Quest for Truth) In Theron, P. F. and Kinghorn, J. (eds)., Koninkryk, Kerk en Kosmos. (Kingdom, Church and Cosmos.) Volume in honour of W. D. Jonker's 60th birthday. Bloemfontein: ProChristo, 11-32.

Smit, D. J. 1992. Kerkeenheid in die Ekumene. (Church Unity in Ecumenical Circles.) Apologia. Bellville: UWK, 43-52.

Smit, D. J. 2008. Ecclesiological Foundations for More Visible Forms of Communion? A Southern African Response to the Leuenberg Ecclesiology of "The Church of Jesus Christ". Address at LutheranReformed Joint Commission, Buenos Aires, Argentina, 39 October 2008.

Smit, D. J. 2010a. What Kind of Unity Do We Want (and Need)? - Progress (and Failures) of the Reformed Churches in South Africa on Their Way to Full Communion. Paper delivered at Consultation of the CPCE and the Ev. Church in Hessen Nassau on "The Community of Protestant Churches in Europe as a fellowship of Churches". 1519 September 2010. Online at http://www.zentrumoekumeneekhn.de/ fileadmin/content/Materialien/Dokumentationen/GEKE_Dokumentationen.pdf. [2010 March, 30].

Smit, D. J. 2010b. The Belhar Confession and Church Unity. Address at the Cape Synod of URCSA, 28 September 2010.

Louw, N. P. van W. 1960. Voorwoord. (Preface.) In Botha, Die Opkoms van ons Derde Stand. (The Rise of Our Third Estate.) Cape Town: Human and Rousseau.

Van Wijk A. J. (ed.). 1964. Die Ekumene. (The Ecumenical Church.) Stellenbosch: KosmoUitgewery. 
NGTT Deel 54, Nommers 3 \& 4, September en Desember 2013

Vischer, L. 2000. Pia Conspiratio. Calvin's Legacy and the Divisions of the Reformed Churches Today. Geneva: WARC.

Visser 't Hooft, W. A. 1958. Tot Eenheid Geroepen. Nijkerk: Callenbach.

Vorster, J. D. (ed.). 1978. Veelvormigheid en Eenheid. (Diversity and Unity.) Cape Town: NG Kerk.

Vorster, J. D. 1978. Meervormigheid in die Eenheid. (Pluriformity in the Unity.) In Vorster, Pluriformiteit en Eenheid. Cape Town: NG Kerk.

WARC 2007. What is the Significance of Calvin's Legacy for Christians Today? Report of an International Consultation, held from April 15 to 19, 2007 in Geneva, with the John Knox International Reformed Center Geneva; Federation of Swiss Protestant Churches; Faculty of Theology, University of Geneva.

\section{KEY WORDS}

Ecclesiological quest

One, reconciled, visible body

One communion

Diversity in unity

Belhar Confession

The world believe

\section{TREFWOORDE}

Ekklesiologiese soeke

Een, versoende, sigbare liggaam

Een gemeenskap

Diversiteit in gemeenskap

Belhar Belydenis

Dat die wêreld mag glo

Contact Details/Kontakbesonderhede

Dr. Johan Botha

Research associate in the Faculty of Theology,

Stellenbosch University

South Africa

scriba@vgksa.org.za 